\title{
The Psychology of the Corrupt: Some Preliminary Findings
}

Nee, C., Button, M., Shepherd, D., Blackbourn, D. and Leal, S.

\begin{abstract}
This article presents findings based on the psychological profile of 17 offenders who have been convicted of occupational fraud, bribery or related offences. It provides findings on their specific psychological profiles using well established psychological techniques to gauge personality. The study is aimed to provide the foundations for further research on such profiles, which could eventually provide a screening tool to identify individuals who might be a higher risk of engaging in corrupt behaviours for organisations.
\end{abstract} Purpose - The purpose of this study was to examine the psychological profile of persons convicted of corruption.

Design/methodology/approach - The research is based upon 17 interviews with white collar offenders who were also asked to complete an Eysenck Personality Questionnaire to identify their profile.

Findings - The study found its subjects to gregarious, outgoing, agreeable, emotionally controlled possessing an ability to lie and manipulate, thus personable liars.

Research limitations/implications - The study is based on only a small sample but the findings suggest more research is required on the psychological profile of offenders convicted of corruption related offences.

Practical implications - This study should prompt further research which could yield tools to identify persons at higher risk of engaging in corruption. 
Originality/value - It's a unique study on individual convicted of corruption identifying their psychological characteristics.

Keywords White collar crime, occupational corruption, psychological profile Paper type Research paper

\section{Introduction}

There are many consultancy firms offering tailored 'magic bullet' solutions to the problem of preventing staff fraud and corruption in exchange for large fees. There are also numerous practitioner texts which set out more generalised approaches that can be adapted to specific organisational needs, for example, Comer (2003), Giles (2012) and Wells (2007). Unfortunately the solutions offered are frequently based on dubious research or no research at all (Levi and Burrows, 2008). Staff screening is frequently promoted as an essential component of a counter fraud and corruption strategy (Button and Gee, 2013, p87; Tunley et al, 2017). The principal purpose of the screening is to filter out those individuals who might harm the employing organisation through their fraudulent and corrupt behaviour. Recruitment vetting processes typically involve checking qualifications, experience and employment histories. Sometimes they include deeper enquiries into security matters, criminal records, finances and lifestyle. Occasionally candidates are subjected to psychometric testing (Edenborough, 2005). However, predicting white-collar crime risks based on assessed personality traits is highly subjective as there has been very little research into the correlation of personality traits with white-collar criminality (Collins and Schmidt 1993; Blickle, Schlegel, Fassbender and Klein, 2006). 
This study provides some preliminary findings on the psychological profile of a small group of offenders who had been convicted of white-collar offences which could be described as 'occupational corruption'. The essence of most definitions of corruption is the abuse of trust for the gain of oneself or a particular group (Johnson and Sharma, 2004, p2). It encompasses a very wide range of behaviours from misappropriation of funds, acceptance of improper gifts, non-performance of duties, fraud and bribery (Langseth, 2006, p11; Transparency International, 2011). This study involved those in positions of trust who were convicted of occupational fraud, bribery or related conspiracy offences. The people who engage in these forms of occupational corruption tend to come from the higher status occupations, as they have the opportunity to engage in such practices. Shover and Hunter (2010, p220) have noted, 'Upper world white collar criminals are the least studied and least interpreted subjects of criminological interest, and they present a formidable set of problems for investigators.' It is therefore a unique study based upon interviews with 17 convicted of such offences in the field and not in prison or under the auspices of parole/probation. Each of the offenders were interviewed and then asked to complete the Eysenck Personality Questionnaire - Revised (EPQ-R) (Eysenck, Eysenck and Barratt, 1985) to assess their personality traits. It is a very small sample, nevertheless it yielded some interesting findings which warrant further research. The paper will begin be setting out the methods for this study. It will then examine some of the previous research on the psychology of offenders in general and for white-collar criminals in particular. Finally the paper will then present the findings from this study as well as identifying some of its limitations.

\section{Methods}


This research sought to interview persons sanctioned for 'occupational corruption' in the field not in prison or under the auspices of probation. Most interview studies of white collar offenders have been based upon interviewing offenders in prison or under the auspices of probation/parole, (Benson, 1990; Benson and Cullen, 1988; Cressey, 1953; GoldstrawWhite, 2012). This approach has been criticised, as the offender is driven to 'impress prison officials' and will 'obscure the truth of their crimes in order to gain favours' (Copes and Hochsteler, 2010, p52). Finding and accessing those convicted of occupational corruption outside of the criminal justice system is not straightforward. There is no ready directory with addresses to contact. In order to achieve the aims of the project the researchers pursued the following strategy.

There are a variety of databases where it is possible to identify individuals sanctioned for corruption or regulating bodies which list all cases on their website. The authors used the following:

- Law pages which is a database that law professionals voluntarily add details of cases (general fraud, corruption, misconduct in a public office related criminal offences were identified). The researchers estimate this covers about 10 percent of all the cases in this area.

- Law enforcement and regulatory websites which detail successful cases (Serious Fraud Office and Financial Services Authority).

- Other relevant websites (for example, British Horse Racing Authority, World Snooker, Football Association).

- General media searches for cases. 
The search period covered cases between 2004 and 2013. All the identified offenders were added to a database created specifically for the study. Further searches were undertaken to populate the database with information about their cases. The completed database comprised 471 offenders, the vast majority of whom had received a criminal conviction. In many of these cases there was some information related to an address. For example often a media report will state something like 'Fred Bloggs of $\mathrm{X}$ road, Tunbridge Wells was convicted of...'. Some regulatory sanction reports actually published the offenders' complete addresses (such as the FSA). In the next stage the researchers used publicly available people tracing to source additional addresses. As a result 123 traceable offenders were identified and sent letters inviting them to participate in research interviews. Some wrote back, declining the invitation as it brought back painful memories; some did not respond and some were returned as no longer at this address. The effort, however, did secure 13 participants, which subsequently led to a further 4 secured from those 13 . Some interviewees had built up their own networks and were keen the researchers should also interview these contacts. This approach is clearly a time consuming method with a high attrition rate, as has been noted by other researchers (Shover and Hunter, 2010). However, the method yielded 17 'white-collar offenders', 'in the field', all sanctioned for 'occupational corruption' related offences, and they were secured without connection to criminal justice or regulatory bodies. All the interviews were recorded and transcribed and took place in either a neutral location or the interviewees' homes. At the end of the interview they were asked to complete the Eysenck Personality Questionnaire-Revised (EPQ-R), which is the focus of this paper. This is a well-established and robust scale of general personality and was chosen because it retains high reliability and validity (Caruso, Witkiewitz, Belcourt-Dittloff and Gottlieb, 2001), while being short enough (57 items) to administer to participants after an 
interview, avoiding fatigue. It has also been used with the both the general population and populations of offenders, so is useful for comparison purposes (Fox, Coning and Leicht, 2003). The EPQ-R has four scales. The E scale measures extraversion and high scorers in the general population tend to be outgoing, impulsive, uninhibited, have many social contacts and often take part in group activities. The P scale was originally set out to measure psychotisicm but in recent research has been argued to measure to psychopathy (Heym, Ferguson and Lawrence, 2013). High P scale scorers in the general population tend to be cruel, inhumane, socially indifferent, hostile, aggressive and intolerant. The $\mathrm{N}$ scale measures neuroticism and high scorers tend to be emotionally over-responsive, have difficulties calming down, suffer high levels of anxiety and depression; and the $L$ (lie) scale measures impression management or 'faking good'. As our age range was so broad, we used the average norms associated with the entire age range in the EPQ- $R$, from $16-70$, to reflect our sample.

The 17 participants could be distinguished into the following offending categories:

- 2 bribe payers (Active bribers - they made the move to bribe, rather than were asked to)

- 2 bribe takers (Passive bribees- they were offered the bribe, rather than asked for it)

- 9 abuse of position (fraud)

- 4 conspirators (one was leader of bribing conspiracy, but did not actually pay the bribe, the others were minor players supporting either a fraud or bribery scheme with promises of payments)

The sample frame has limitations. Firstly, the small sample size alone means that that the study's findings cannot be generalised to the wider population of white-collar offenders 
involved in fraud and corruption. However, it is important to note that significant findings can be found from small scale studies. Guest, Bunce and Johnson (2006) found that $97 \%$ of the 'important' codes were identified from the first 12 interviews and Bertaux (1981) has argued that 15 interviews should be the minimum for a qualitative study. Secondly, given that bribery is much rarer than fraud in terms of convictions, the sample over-represents this type of occupational corruption (Ministry of Justice, 2016). Thirdly, the self-selecting nature of the participants may introduce a bias.

However, despite these limitations, the demographic profile is similar to two significant studies which have focussed upon fraud and corruption-related offenders (Table 1). The Bussmann and Werle (2007) study provides the largest and most rigorous study and the KPMG (2011) a large global study. These studies show a significant dominance of men and the middle-aged, which reflects the interviewees. The participants were categorised according to the Standard Occupational Classification (SOC) hierarchy used in the UKi. The SOC ranges from managers, directors and senior officials in group 1 at the top to 'elementary' occupations such as unqualified farm workers and cleaners in group 9 at the bottom. Reflecting a professional, white collar status, $88 \%$ of the interviewees were employed in the top 3 SOC groups: $29 \%$ in the top two groups and 59\% were managers in Group 1. The researchers are therefore confident that this group of interviewees sufficiently reflects the wider group of 'white collar criminals' in terms of gender, age and occupational status in order to produce robust hypotheses for further research.

Table 1. Comparing the demographic profile of interviewees to other studies

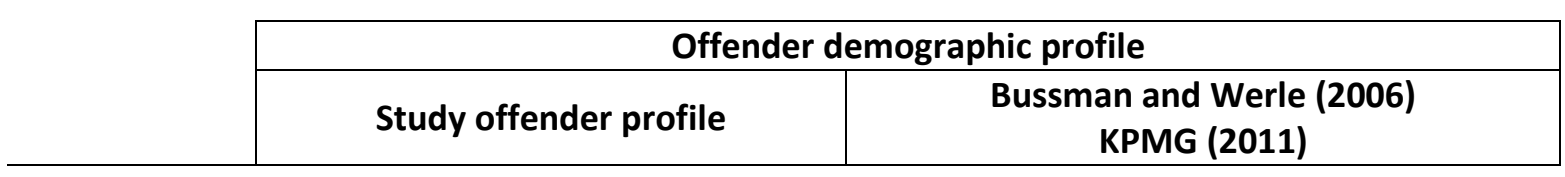




\begin{tabular}{|l|l|l|}
\hline \multirow{2}{*}{ Gender } & $\begin{array}{l}88 \% \text { - male } \\
12 \% \text { - female }\end{array}$ & $\begin{array}{l}87 \% \text { - male (B \& W and KPMG) } \\
13 \% \text { - female (B \& W and KPMG) }\end{array}$ \\
\hline \multirow{3}{*}{ Age } & $18 \%$ - age 18-40 & $71 \%$ - age 31-50 (B \& W) \\
& $53 \%$ - age 41-60 & $76 \%$ - age 36-55 (KPMG) \\
& $29 \%$ - age over 60 & $55 \%$ - management (B \& W) \\
\multirow{2}{*}{$\begin{array}{l}\text { Occupational } \\
\text { status }\end{array}$} & $\begin{array}{l}59 \% \text { (SOC Group 1 and 2) } \\
29 \% \text { (SOC Group 3 and 4) } \\
12 \%(\text { SOC Group 7) }\end{array}$ & $82 \%$ - management (KPMG) \\
\hline
\end{tabular}

\section{Previous Personality Research on Offenders}

Previous research (for example, Aleixo and Norris, 2000; Eysenck and Gudjonssen, 1989; Hollin, 1989) indicates that the broader offending population scores very high on the extraversion scale (usually around 9/12) compared to the general population (Table 2); higher than average on the P scale, which to all intents and purposes measures psychopathy (usually around 5); higher than average on the $\mathrm{N}$ scale (around 6) and lower than average on the Lie scale (around 3). Two previous studies examining personality traits of white collar criminals in general produced mixed results. Collins and Schmidt (1993) in a sample of over 300 offenders found evidence of traits aligned with psychopathy (irresponsibility, unreliability and shunning of norms). Blickle et al (2006) in 76 offenders also found hedonism, narcissism and low self-control but high conscientiousness. In the absence of previous personality assessments of bribers per se and as our small sample of offenders were older, considerably better educated and with far fewer convictions than an average acquisitive offender, we felt it more methodologically sound to compare them with the general population in this exploratory research.

\section{Findings from this Research}

Table 2 below summarises the findings of the personality survey on the sample. As indicated, our sample were significantly higher than the general population on the E scale, 
suggesting they were higher in sensation seeking and impulsivity and lower in selfregulation and anger control. It should be noted that the E scale is also associated with low concentration and aggression, which explains the similarly high E scale score in the general offending population. However, given that the individuals assessed were generally functioning in demanding professional occupations and with few criminal convictions, it is reasonable to suggest that low concentration and high aggression would not be strongly associated with the participants. It is postulated that sensation seeking, risk appetite, impulsivity and lower non-aggressive self-regulation dominate the E scale traits of whitecollar offenders. Further research is required to test this hypothesis using larger, representative samples of white-collar criminals. It is important to add that, when samples sizes are small, the statistical effect size (in this case Cohen's d) throws extra light onto the analysis as it measures the percentage of variance explained by the statistical test. In the case of the $E$ scale scores, the effect size is large, explaining about $40 \%$ of the variance in the statistical outcome. Despite the sample being small, this considerably strengthens the $E$ scale finding.

The P scale results were initially surprising in that the sample emerged as more agreeable than average and not statistically significantly different from the general population. However, on reflection, it may well be that agreeableness is an advantage to successful white-collar criminals who seek to induce others into their corrupt schemes. Furthermore, agreeableness may also be a trait that corruptors instinctively look for in their targets. The average $\mathrm{N}$ scale score indicated this sample was more emotionally stable than the general population, though not significantly so. Finally, participants scored significantly higher on the Lie scale than the general population. This indicated that they were faking good and may 
explain something about their 'over-agreeableness' on the P score. Additionally, the effect size of this finding was substantial, explaining two thirds of the variance in the statistical score.

Table 2. Participants' EPQ-R scores in relation to norms of the general population

\begin{tabular}{|c|c|c|c|c|}
\hline & $\begin{array}{l}\text { Study sample } \\
\text { Average } \\
\text { score/12 } \\
\text { M } \\
\text { (SD) }\end{array}$ & $\begin{array}{c}\text { General } \\
\text { offending } \\
\text { population } \\
\text { score }\end{array}$ & $\begin{array}{l}\text { General } \\
\text { population } \\
\text { score }\end{array}$ & $\begin{array}{l}\text { Significantly } \\
\text { different to } \\
\text { general } \\
\text { population? }\end{array}$ \\
\hline $\begin{array}{c}\text { E SCALE } \\
\text { outgoing, impulsive, } \\
\text { uninhibited, socially active }\end{array}$ & $\begin{array}{c}8.7 \\
(3.45)\end{array}$ & 9 & 5.68 & $\begin{array}{c}\mathbf{v} \\
(t=2.79, p=.013, \\
d=0.65)\end{array}$ \\
\hline $\begin{array}{c}\text { P SCALE } \\
\text { cruel, inhumane, socially } \\
\text { indifferent, hostile, } \\
\text { aggressive, not considerate } \\
\text { of danger, loner, glacial, and } \\
\text { intolerant }\end{array}$ & $\begin{array}{c}2.47 \\
(1.73)\end{array}$ & 5 & 2.7 & $\begin{array}{c}x \\
(t=0.167)\end{array}$ \\
\hline $\begin{array}{c}\text { N SCALE } \\
\text { emotionally over- } \\
\text { responsive, difficulties } \\
\text { calming down, high levels of } \\
\text { anxiety and depression }\end{array}$ & $\begin{array}{c}4.8 \\
(3.23)\end{array}$ & 6 & 5.16 & $\begin{array}{c}\mathrm{X} \\
(\mathrm{t}=0.816)\end{array}$ \\
\hline $\begin{array}{l}\text { L SCALE } \\
\text { faking good }\end{array}$ & $\begin{array}{c}6.0 \\
(2.71)\end{array}$ & 3 & 4.24 & $\begin{array}{c}\mathbf{v} \\
(t=3.25, p=.005, \\
d=1.16)\end{array}$ \\
\hline
\end{tabular}


This preliminary research suggests these are not 'run-of-the-mill' offenders in terms of personality. It furnishes researchers with a number of hypotheses to follow up. The combination of high extraversion, agreeableness, emotional stability and faking good suggests a strong association with the more 'cognitive' side of psychopathy known as Factor 1 (Hare, 2003). Although the nature of psychopathy has been the subject of considerable debate in recent years (Cooke, Michie and Skeem, 2007) few would dispute that, at minimum, elements include lack of remorse, callousness and an ability to manipulate (traditionally know as Factor 1) combined with (what many see as Factor 2) a more behavioural element characterised by lack of control and sensation seeking (Blackburn, 1998). In contrast, our sample seemed to be gregarious, outgoing, agreeable, emotionally controlled but with an ability to lie and manipulate. The findings suggest that white-collar offenders involved in occupational fraud and bribery are personable liars. As such, our findings are somewhat closer to those of Blickle et al (2006) who found high conscientiousness than Collins and Schmidt (1993) who found what they termed as low 'social conscientiousness'. Both samples were more varied than ours however and found high levels of impulsivity. Our offenders, in contrast, who were predominantly involved in occupational corruption, appeared to have higher emotional stability and self-control than is typical. It suggests those who engage in occupational corruption may present as successful job applicants. It appears that recruiters should not be blinded by the convivial charm of applicants and ought to screen for white-collar crime risks with dishonesty testing. Future research should examine these hypotheses in more depth with larger samples and comparison groups, using tests of psychopathy, general personality and a separate deception or 'Lie' scale. 


\section{Limitations}

It cannot be overstated that we consider this research as preliminary and indicative rather than definitive given the small sample and its self-selecting nature. Nevertheless, the sample was close to the typical demographics of much larger samples of white-collar offenders to produce some clear and interesting trends, with large effect sizes, regarding personality. These differ from the general population and studies with more 'typical' offender populations. It is important to follow up on these preliminary findings and research these issues further. Additionally, caution must be borne in mind when interpreting results in future studies, as many successful figures in the corporate world score higher than the average population on personality disorder scales and this should be taken into account (Board and Fritzon, 2005).

\section{Conclusions}

This small study has furnished us with some hitherto unknown trends about this population that deserve more attention. We know from preliminary work on expertise in fraudsters that, unlike most offenders, many come from within the organisation that they target (Nee and Ward, 2015; Vieritus, Copes, Parker and Pike, 2015) and clearly, we ignore the offender's understanding of their offence at our peril (Nee, 2010). It is therefore important that we try to understand the types of individuals that engage in different types of corruption much more clearly. This will allow us to more fully understand the nature and extent of the crime, potentially predict who are 'high risk' recruits using psychometric testing, improve situational crime prevention by changing our practices and reducing opportunities, and improve rehabilitation techniques with offenders by knowing better where the problems lie. 


\section{References}

Aleixo, P.A. and Norris, C.E. (2000). Personality and moral reasoning in young offenders. Personality and Individual Differences, 28, 609-623.

Benson, M.L. (1990). Emotions and Adjudication: Status Degradation Among White-Collar Criminals. Justice Quarterly, 7, 515-528.

Benson, M.L. and Cullen, F. (1988). The special sensitivity of white collar-offenders to prison: A critique and research agenda. Journal of Criminal Justice, 16, 207-215.

Bertaux, D. (1981). From the life-history approach to the transformation of sociological practice. In D. Bertaux (Ed.), Biography and society: The life history approach in the social sciences. London: Sage.

Blickle, G., Schlegel, A., Fassbender, P. and Klein, U. (2006). Some personality correlates of business white-collar crime. Applied Psychology: An International Review, 55, 220-233.

Blackburn, R. (1998). Psychopathy and Personality Disorder: Implications of Interpersonal Theory. In David J. Cooke, Adelle E. Forth, Robert D. Hare (Eds). Psychopathy: Theory, Research and Implications for Society. Springer Verlag.

Board, B.J. and Fritzon, K. (2005). Disordered personalities at work. Psychology, Crime \& Law, 11(1), 17-32.

Bussmann, K.D. and Werle, M.M. (2006) Addressing Crime in Companies First Findings from a Global Survey of Economic Crime. British Journal of Criminology, 46, 1128-1144. 
Button, M. and Gee, J. (2013). Countering Fraud for Competitive Advantage. Chichester: Wiley.

Caruso, J. C., Witkiewitz, K., Belcourt-Dittloff, A. and Gottlieb, J.D. (2001) Reliability of Scores from the Eysenck Personality Questionnaire: A Reliability Generalization Study. Educational and Psychological Measurement. 61, 675-689.

Collins, J.M. and Schmidt, F.L. (1993) Personality, Integrity and White Collar Crime: A Construct Validity Study. Personnel Psychology, 46, 295-311.

Comer, M. (2003). Investigating Corporate Fraud. Aldershot: Gower.

Cooke, D.J., Michie, C. and Skeem, J. (2007). Understanding the structure of the psychopathy checklist - revised: an exploration of methodological confusion. The British Journal of Psychiatry, Supplement, 49, s39-50. doi:10.1192/bjp.190.5.s39

Copes, H. and Hochstetler, A. (2010). Interviewing the Incarcerated: Pitfalls and promises. In Bernasco, W. (ed) Offenders on Offending. Cullompton: Wilan.

Cressey, D. (1953). Other People's Money. Belmont: Wadsworth Publishing.

Edenborough, R. (2005). Assessment Methods in Recruitment, Selection and Performance: A Manager's Guide to Psychometric Testing, Interviews and Assessment Centres. London: Kogan Page.

Eysenck, S.B., Eysenck, H.J. and Barrett, P. (1985). A revised version of the psychoticism scale. Personality and Individual Differences. 6 (1), 21-29. doi:10.1016/01918869(85)90026-1. 
Eysenck, H.J. and Gudjonsson, G.H. (1989). The causes and cures of criminality. New York: Plenum Press.

Fox, S., Coning, E., and Leicht, S. (2003). The relationship between attribution of blame for a violent act and EPQ-R sub-scales in male offenders with mental disorder. Personality and Individual Differences. 34(8), 1467-1475.

Giles, S. (2012). Managing Fraud Risk: A Practical Guide for Directors and Managers. Chichester: Wiley.

Goldstraw-White, J. (2012). White Collar Crime Accounts of Offending. Basingstoke: Palgrave.

Guest, G., Bunce, A. and Johnson, L. (2006). How Many Interviews Are Enough? An Experiment with Data Saturation and Variability. Family Health International, 18(1), 59-82.

Hare, R.D. (2003). The Hare Psychopathy Checklist-Revised, 2nd Edition. Toronto, ON, Canada: Multi-Health Systems.

Heym, N., Ferguson, E. and Lawrence, C. (2013). The P-psychopathy continuum: Facets of Psychoticism and their associations with psychopathic tendencies. Personality and Individual Differences, 54(6), 773-778. doi:10.1016/j.paid.2012.12.001

Hollin, C. (1989). Psychology and crime: An introduction to criminological psychology. London: Routledge.

Johnston, R.A. and Sharma, S. (2004). About Corruption. In, Johnston, R., A. (ed.) The Struggle Against Corruption. Basingstoke: Palgrave. 
KPMG (2011). Who is the Typical Fraudster. London: KPMG.

Langseth, P. (2006). Measuring corruption. In C. Sampford, A. Shacklock, C. Connors and F. Galtung (Eds.), Measuring Corruption. London: Routledge.

Levi, M. and Burrows, J. (2008). Measuring the Impact of Fraud in the UK: A Conceptual and Empirical Journey. British Journal of Criminology 48 (3) 293-318.

Ministry of Justice (2016). Experimental statistics on proceedings and outcomes by Home Office offence code. Retrieved from: https://www.gov.uk/government/statistics/criminaljustice-system-statistics-quarterly-december-2015

Nee, C. (2010). Research on residential burglary: ways of improving validity and participants' recall when gathering data. In W. Bernasco (Ed.). Offenders on Offending: Learning about Crime from Criminals. Devon: Willan Press.

Nee, C. and Ward, T. (2015). Review of expertise and its general implications for correctional psychology. Special issue on expertise and offending behavior. Aggression and Violent Behavior 20: 1-9. DOI: 10.1016/j.avb.2014.12.002

Shover, N. and Hunter, B. W. (2010). Blue-collar, white-collar: crimes and mistakes. In Bernasco, W. (ed.), Offenders on Offending. Cullompton: Wilan.

Transparency International (2011). Corruption in the UK: overview and policy recommendations. Retrieved from the TI website: http://www.transparency.org.uk/publications/corruption-in-the-uk-overview-policyrecommendations/ 
Tunley, M., Button, M., Shepherd, D. and Blackbourn, D. (2017). Preventing occupational corruption: utilising situational crime prevention techniques and theory to enhance organisational resilience. Security Journal. doi:10.1057/s41284-016-0087-5

Vieraitis, L., Copes, H., Powell, Z. and Pike, A. (2015). A little information goes a long way: expertise and identity theft. Aggression and Violent Behavior, 20, 10-18.

\footnotetext{
i Occupational status codes were drawn from the Office for National Statistics Occupational Coding Tool (found at http://www.neighbourhood.statistics.gov.uk/HTMLDocs/dev3/ONS SOC occupation coding tool.html). This divides occupations into 9 major groups with 1 the highest status and 9 the lowest.
} 